\title{
CLINICAL AND NUTRITIONAL STATUS OF SURGICAL PATIENTS WITH AND WITHOUT MALIGNANT DISEASES: cross-sectional study
}

\author{
Vânia Aparecida LEANDRO-MERHI', José Luiz Braga de AQUINO'1, \\ José Gonzaga Teixeira de CAMARGO ${ }^{2}$, Patrícia Baston FRENHANI ${ }^{1}$, \\ Júlia Laura Delbue BERNARDI ${ }^{1}$ and Kátia Cristina Portero McLELLAN ${ }^{1}$
}

\begin{abstract}
Context - Malnutrition is frequently observed in inpatients with malignant diseases and may contribute to longer hospital stays. Objective - To compare the nutritional status, lymphocyte count, hemoglobin values and length of hospital stay of patients with and without malignant diseases. Methods - This comparative study assessed indicators of nutritional status, namely body mass index, recent weight loss, lymphocyte count, hemoglobin and length of hospital stay, of 928 surgical patients with and without malignant diseases $(50.2 \%$ females and $49.8 \%$ males). The chi-square test was used to compare proportions and the Mann-Whitney test was used to compare continuous measurements between two groups. The significance level was set at $5 \%$. Results - Patients with malignant diseases had longer hospital stays $(P<0.0001)$, furthermore, a higher percentage of patients with malignant diseases had body mass index $<18.5(P<0.0001)$ and experienced recent weight changes $(P<0.0002)$. Lymphocyte count also differed statistically between the groups $(P=0.0131)$, which lower levels were identified among patients with malignant diseases. Conclusion - The lymphocyte count, hemoglobin values and weight loss are important findings of nutritional depletion in patients with malignant diseases.
\end{abstract}

HEADINGS - Nutritional status. Weight loss. Blood cell count. Length of stay.

\section{INTRODUCTION}

Malnutrition is a common problem among patients with malignant diseases. It is associated with increased risk of complications and reduced response to treatment. Both age and disease can affect nutritional status by numerous ways ${ }^{(6)}$. Malnutrition may be due to the local effect of the tumor as well as to antineoplastic therapies ${ }^{(26)}$ and, although neoplastic patients frequently have a low energy intake (given the systemic effects of the disease, local effect of the tumor, psychological effects or adverse effects of treatment), changes in nutrient metabolism and energy expenditure can also influence nutritional status ${ }^{(26)}$. On the other hand, excess body weight and physical inactivity are also recognized as nutritional risk factors among neoplastic patients ${ }^{(4)}$.

Advances in the diagnosis and treatment of the disease have greatly improved its prognosis, enhancing survival time and quality of life. However, cancer-associated weight loss is common and well known to occur in this population and it negatively impacts tolerance to antineoplastic therapy and cure or control of the disease ${ }^{(19)}$. Energy-protein malnutrition in cancer patients presents itself as a physical constitution disorder given the absence of homeostasis between nutrient intake and requirements, impairing body functions and promoting biochemical changes and weight loss ${ }^{(8)}$. Wasting is not unusual ${ }^{(19)}$ and is characterized by loss of weight and lean mass accompanied by changes in energy-protein intake, dysphagia, odynophagia, xerostomia, dysgeusia, intestinal obstipation, nausea, vomiting, diarrhea, early satiety, functional impairment and also systemic metabolic changes ${ }^{(3,5,10,25)}$. Wasting has led to the search of methodologies that assess nutritional status and provide early detection of patients at risk of malnutrition ${ }^{(16,24)}$. Based on the facts discussed above, the objective of this study was to compare the nutritional status, lymphocyte count, hemoglobin values and length of hospital stay of patients with and without malignant diseases.

\section{METHODS}

The patients included in this study were evaluated between February 2007 and December 2007, selected

Research Group: Surgical Therapeutics of Cervicothoracic Transition Diseases Sources of funding: Not declared

Conflict of interest: None

${ }^{1}$ School of Nutrition; ${ }^{2}$ School of Medicine - Pontifica Universidade Católica (PUC) - Campinas - SP, Brazil;

Correspondence: Vânia A. Leandro-Merhi. Av. Carlos Grimaldi,171, Quadra D, Lote 13, Jardim Madalena - Residencial Vila Verde - 13091-906- Campinas, SP, Brazil. E-mail: valm@dgInet.com.br 
from the databank of the project "Nutritional Diagnosis and Intervention of Inpatients and Outpatients" which was approved by the Pontífica Universidade Católica, Campinas, SP, Brazil, Research Ethics Committee (Protocol no. 504/05). This cross-sectional study divided 928 adults inpatients of both genders $(50.2 \%$ females and $49.8 \%$ males) into two groups: inpatients with malignant diseases $(\mathrm{n}=179 / 19.3 \%)$ and inpatients without malignant diseases ( $\mathrm{n}=749 / 80.7 \%$ ). The retrospective calculation of sample size was performed with a significance level of $95 \%$, based on the total population assessed; therefore, the population with cancer evaluated in this study was representative of that population. All of them stayed in the Clinical Surgery Ward of the Hospital and Maternity Celso Pierro, Campinas, SP, Brazil.

The data were collected with the use of a previously defined nutritional care protocol. Identification information and diagnosis were obtained from the medical record. The following indicators of nutritional status were analyzed: body mass index (BMI), recent weight loss (RWL), lymphocyte count, hemoglobin and length of hospital stay. BMI was determined by dividing weight by height squared $\left(\mathrm{kg} / \mathrm{m}^{2}\right)$ and classified according to the criteria established by the World Health Organization ${ }^{(27)}$, for adults under 60 years of age and according to Lipschitz ${ }^{(11)}$, for adults aged 60 years or older. RWL was given a yes for those who lost weight during their hospital stay and no for those who did not lose weight during their hospital stay.

Lymphocyte count (LC) and hemoglobin classifications were based on reference values ${ }^{(9,12)}$. Additionally, the following LC ranges were used to classify nutritional depletion: no depletion if $\mathrm{LC}>1500 \mathrm{~mm}^{3}$; mild depletion if $1500 \geq \mathrm{LC} \geq 1200$ $\mathrm{mm}^{3}$; moderate depletion if $1200 \geq \mathrm{LC} \geq 800 \mathrm{~mm}^{3}$; and severe depletion if $\mathrm{LC}<800 \mathrm{~mm}^{3}$. Plasma hemoglobin levels were considered normal when they ranged from 13.5 to $18 \mathrm{~g} / \mathrm{dL}$ for males and from 12 to $16 \mathrm{~g} / \mathrm{dL}$ for females ${ }^{(9,12)}$.

The assessed indicators (gender, age, length of hospital stay, BMI, RWL, lymphocyte count and hemoglobin) of patients with malignant diseases were compared with those of patients without malignant diseases.

The data were processed by the software Excel and expressed by descriptive statistics followed by SAS (Statistical Analysis System) ${ }^{(21)}$ analysis. The chi-square test was used to compare proportions and the Mann-Whitney test was used to compare continuous measurements between two groups. The significance level was set at $5 \%(P<0.05)$.

\section{RESULTS}

Of the 928 studied patients, $71.2 \%$ were aged 60 years or less, $58.2 \%$ stayed in the hospital for up to 3 days and $19.3 \%$ had malignant diseases; of these, $38.3 \%$ were females and $61.4 \%$ were males (Table 1). The percentage of patients older than 60 years $(P=0.0024)$ and the mean age $(P<0.0001)$ of the patients in the group with malignant diseases were both higher than in the group without malignant diseases (Tables 1 and 2).

There was also a significantly higher percentage of male patients in the group with malignant diseases $(P=0.0005)$.
TABLE 1. Descriptive analysis of the studied population: patients with and without malignant diseases

\begin{tabular}{lccc}
\hline Studied variables & \multicolumn{3}{c}{ Patients } \\
\cline { 2 - 4 } & $\begin{array}{c}\text { With } \\
\text { diseases } \\
\mathbf{n}(\%)\end{array}$ & $\begin{array}{c}\text { Without } \\
\text { malignant } \\
\text { diseases } \\
\mathbf{n}(\%)\end{array}$ & $\begin{array}{c}\text { Total } \\
\mathbf{n}(\%)\end{array}$ \\
\hline $\begin{array}{l}\text { Gender } \\
\text { Females }\end{array}$ & $69(38.5)$ & $397(53.0)$ & $466(50.2)$ \\
Males & $110(61.4)$ & $352(47.0)$ & $462(49.8)$ \\
Total & $179(19.3)$ & $749(80.7)$ & $928(100.0)$ \\
$P$-value (chi-square) & 0.0005 & & \\
\hline $\begin{array}{l}\text { Age } \\
\leq 60 \text { years }\end{array}$ & $111(62.0)$ & $550(73.4)$ & $661(71.2)$ \\
$>60$ years & $68(38.0)$ & $199(26.6)$ & $267(28.8)$ \\
Total & $179(19.2)$ & $749(80.7)$ & $928(100.0)$ \\
$P$-value (chi-square) $)$ & 0.0024 & & \\
\hline $\begin{array}{l}\text { Length of } \\
\text { hospital stay }\end{array}$ & & & \\
Up to 3 days & $72(40.4)$ & $468(62.5)$ & $540(58.2)$ \\
$4-7$ days & $57(32.0)$ & $177(23.6)$ & $234(25.2)$ \\
$>7$ days & $49(27.6)$ & $104(13.9)$ & $153(16.5)$ \\
Total & $178(19.2)$ & $749(80.8)$ & $927(100.0)$ \\
$P$-value (chi-squan & &
\end{tabular}

$P$-value (chi-square) $\leq 0.0001$

TABLE 2. Comparison of the studied variables between patients with and without malignant diseases

\begin{tabular}{|c|c|c|c|c|}
\hline & $\mathrm{n}$ & Mean & $\begin{array}{l}\text { Standard } \\
\text { deviation }\end{array}$ & Median \\
\hline \multicolumn{5}{|l|}{ BMI $\left(\mathrm{kg} / \mathrm{m}^{2}\right)$} \\
\hline With malignant diseases & 163 & 23.18 & 5.58 & 23.31 \\
\hline Without malignant diseases & 687 & 24.87 & 5.17 & 24.19 \\
\hline \multicolumn{5}{|c|}{$P$-value $($ Mann-Whitney $)=0.0004$} \\
\hline \multicolumn{5}{|l|}{$\begin{array}{l}\text { Length of hospital } \\
\text { stay (days) }\end{array}$} \\
\hline With malignant diseases & 178 & 6.5 & 6.5 & 4.0 \\
\hline Without malignant diseases & 749 & 4.7 & 5.9 & 3.0 \\
\hline \multicolumn{5}{|c|}{$P$-value $($ Mann-Whitney $)<0.0001$} \\
\hline \multicolumn{5}{|l|}{ Lymphocytes $\left(\mathrm{mm}^{3}\right)$} \\
\hline With malignant diseases & 98 & 1734.1 & 909.2 & 1630.0 \\
\hline Without malignant diseases & 358 & 1993.7 & 1046.4 & 1895.0 \\
\hline \multicolumn{5}{|c|}{$P$-value $($ Mann-Whitney $)=0.0131$} \\
\hline \multicolumn{5}{|l|}{ Age (years) } \\
\hline With malignant diseases & 179 & 57.7 & 13.8 & 56.0 \\
\hline Without malignant diseases & 749 & 49.1 & 17.0 & 49.0 \\
\hline \multicolumn{5}{|c|}{$P$-value $($ Mann-Whitney $)<0.0001$} \\
\hline
\end{tabular}

There was a statistical difference between groups regarding length of hospital stay $(P \leq 0.0001)$; most patients without malignant diseases $(62.5 \%)$ stayed in the hospital for up to 3 days while most patients with malignant diseases stayed for longer periods. Yet, the greatest difference in percentages was observed among patients who stayed in the hospital for up to 3 days (Table 1). The mean lengths of hospital stay also differed statistically between the two groups $(P<0.0001)$ (Table 2$)$. 
Tables 2 and 3 also show that there is a significant difference between the mean BMI of patients with malignant diseases and that of patients without malignant diseases $(P$-value $=$ $0.0004 /$ Mann-Whitney and $P$-value $<0.0001 /$ chi-square). The percentage of patients with $\mathrm{BMI}<18.5$ and the percentage of patients who lost weight during their hospital stay were both significantly higher in the group with malignant diseases $(P<0.0001$ and $P=0.0002$, respectively) (Table 3$)$.

When the ranges of lymphocyte counts with respect to nutritional depletion were compared, no statistical difference was found between the groups $(P=0.1762)$ (Table 3$)$, but when the mean and median were analyzed, a significant difference was found $(P=0.0131)$ (Table 2$)$. A statistically higher percentage of patients with low hemoglobin concentrations was also observed in the group with malignant diseases $(P=0.0007)($ Table 3$)$.

TABLE 3. Descriptive analysis of the nutritional status and comparison of the groups of patients with and without malignant diseases

\begin{tabular}{|c|c|c|c|}
\hline \multirow[b]{2}{*}{ Nutritional status } & \multicolumn{3}{|c|}{ Patients } \\
\hline & $\begin{array}{c}\text { With } \\
\text { malignant } \\
\text { diseases } \\
\mathrm{n}(\%)\end{array}$ & $\begin{array}{l}\text { Without } \\
\text { malignant } \\
\text { diseases } \\
\mathrm{n}(\%)\end{array}$ & $\begin{array}{l}\text { Total } \\
\text { n }(\%)\end{array}$ \\
\hline \multicolumn{4}{|l|}{ BMI $\left(\mathrm{kg} / \mathrm{m}^{2}\right)$} \\
\hline$<18.5$ & $41(25.1)$ & $56(8.1)$ & $97(11.4)$ \\
\hline $18.5-24.9$ & $63(38.6)$ & $330(48.0)$ & $393(46.2)$ \\
\hline $25-29.9$ & $36(22.0)$ & $192(27.8)$ & $228(26.8)$ \\
\hline $30-39.9$ & $22(13.5)$ & $103(14.9)$ & $128(14.7)$ \\
\hline$\geq 40$ & $1(0.6)$ & $6(0.8)$ & $7(0.8)$ \\
\hline Total & $163(19.1)$ & $687(80.8)$ & $850(100)$ \\
\hline \multicolumn{4}{|c|}{$P$-value (chi-square) $<0.0001$} \\
\hline \multicolumn{4}{|l|}{ RWL* } \\
\hline Yes & $110(61.4)$ & $343(46.1)$ & $453(49.0)$ \\
\hline No & $69(38.5)$ & $401(53.9)$ & $470(50.9)$ \\
\hline Total & $179(19.3)$ & $744(80.6)$ & $923(100.0)$ \\
\hline \multicolumn{4}{|c|}{$P$-value $($ chi-square $)=0.0002$} \\
\hline \multicolumn{4}{|l|}{ Lymphocytes } \\
\hline Without depletion & $59(60.2)$ & $243(67.9)$ & $302(66.2)$ \\
\hline Mild depletion & $10(10.2)$ & $44(12.3)$ & $54(11.9)$ \\
\hline Moderate depletion & $17(17.3)$ & $36(10.0)$ & $53(11.6)$ \\
\hline Severe depletion & $12(12.2)$ & $35(9.8)$ & $47(10.3)$ \\
\hline Total & $98(21.5)$ & $358(78.5)$ & $456(100)$ \\
\hline
\end{tabular}

$\begin{array}{lccc}\text { Hemoglobin }(\mathrm{g} / \mathrm{dL}) & & & \\ \text { Normal Hg } & 50(43.8) & 284(61.3) & 334(57.9) \\ \text { Low Hg } & 64(56.1) & 179(38.6) & 243(42.1) \\ \text { Total } & 114(19.7) & 463(80.2) & 577(100.0)\end{array}$

$P$-value (chi-square) $=0.0007$

*RWL - recent weight loss; $\mathrm{Hg}$ - hemoglobin (normal $\mathrm{Hg}$ : plasma hemoglobin concentrations within the normal range of 13.5 to $18 \mathrm{~g} / \mathrm{dL}$ for males and 12 to $16 \mathrm{~g} / \mathrm{dL}$ for females; low $\mathrm{Hg}$ : plasma hemoglobin levels below the normal range)

\section{DISCUSSION}

Patients with malignant diseases are more likely to develop complications during their hospital stay than those without malignant diseases. They may also present more nutritional deterioration. In this study, patients with malignant diseases were usually older, had longer hospital stays and were more nutritionally depleted as indicated by their BMI, RWL, lymphocyte count and hemoglobin. More important, patients with lower BMI were likely to have longer hospital stays: there was an association between lower BMI and a higher number of days in the hospital. In a recent study by Mullen et al. ${ }^{(14)}$ assessing the impact of BMI on the surgery outcomes of cancer patients submitted to intra-abdominal surgery, a difference between length of stay and BMI classes was not found. After adjusting for other risk factors, obesity was not considered a risk factor for death or major complications. The risk of dying after surgery was higher for underweight patients ${ }^{(14)}$.

Inadequate nutritional status results in lower treatment response, greater risk of infections and longer hospital stays ${ }^{(23)}$. The disturbing prevalence of malnutrition among patients with malignant diseases varies from $30 \%$ to $90 \%$, which is in agreement with the results of this study ${ }^{(23)}$. Another study found a $24.2 \%$ prevalence of malnutrition among inpatients with all kinds of diseases and an association between diagnosis and malnutrition where the prevalence of malnutrition was significantly higher in patients with malignant diseases than in patients with non-malignant diseases $(50.9 \%$ versus $21.0 \%$, $P<0.0001)^{(17)}$.

According to Ravasco et al. ${ }^{(19)}$, a patient with a malignant disease is already classified as being at risk of malnutrition because of all the metabolic changes brought about by the disease as well as by the side effects of treatment. Many substances produced by the tumor, such as cytokines and hormones, may be implicated in the pathogenesis of malnutrition and cachexia ${ }^{(26)}$.

A poor nutritional status has also been associated with psychosocial factors ${ }^{(13)}$. After being diagnosed with cancer, patients experience different personal conflicts, such as difficulty to accept the disease, anxiety regarding treatment and the future and fear of family and social discrimination. This situation could somehow change food intake and, consequently, the nutritional status of the patient. Eventually, the patient adapts by restructuring him/herself psychologically, thereby minimizing the side effects of treatment ${ }^{(8)}$.

Severe malnutrition in patients with malignant diseases is associated with increased morbidity and mortality, reduced treatment efficacy and longer hospital stays ${ }^{(22)}$. There are other published studies that report an association between malnutrition and longer hospital stays ${ }^{(1,7,18)}$, and the factors that contribute most to malnutrition are advanced age, malignant diseases and presence of comorbidities.

A study done in Cuba observed that nutritional status is statistically associated with the presence of malignant diseases and infection as a high prevalence of malnutrition was found among cancer patients and postsurgical non-cancer patients $^{(1)}$.

This study found a worrisome percentage of recent weight loss among its participants, particularly among patients with malignant diseases $(P=0.0002): 61.4 \%$ of them lost weight during their hospital stay. It is important to remember that immune 
function starts to deteriorate when weight loss exceeds $15 \% 0^{(15)}$. The fact that patients with malignant diseases also presented lower lymphocyte counts should also be emphasized because of the consequences of lymphocytopenia in this population. There are studies that show a significantly low total lymphocyte count among gastric cancer patients before and after surgery ${ }^{(15)}$. Early enteral nutrition could reduce lymphocytopenia in the postoperative period ${ }^{(15)}$. Another study found significant clinical advantages were observed in malnourished patients and the enteral immunonutrition of head and neck cancer patients improves postoperative immunological response ${ }^{(20)}$.
Nutritional intervention should be implemented as soon as cancer is diagnosed and personalized to meet the specific requirements of the patient, taking into account the type of treatment to be administered and the patient's clinical condition and nutritional status ${ }^{(2)}$.

\section{CONCLUSION}

The lymphocyte count, hemoglobin values and weight loss are important findings of nutritional depletion in patients with malignant diseases.

Leandro-Merhi VA, Aquino JLB, Camargo JGT, Frenhani PB, Bernardi JLD, McLellan KCP. Estado clínico e nutricional de pacientes cirúrgicos com e sem doenças malignas: estudo transversal. Arq Gastroenterol. 2011;48(1):58-61.

RESUMO - Contexto - A desnutrição em pacientes com doenças malignas é frequentemente observada durante a hospitalização e pode acarretar num aumento do período de internação. Objetivo - Comparar o estado nutricional, valores de linfócitos e hemoglobina e o tempo de internação em pacientes com e sem doenças malignas. Métodos - Estudo comparativo com 928 pacientes cirúrgicos com e sem doenças malignas (50,2\% do sexo feminino e $49,8 \%$ do sexo masculino), sendo analisados os indicadores do estado nutricional como índice de massa corporal, perda de peso recente, contagem de linfócitos, hemoglobina e o tempo de internação. Foi aplicado o teste qui ao quadrado para comparação de proporções e para a comparação de medidas contínuas entre dois grupos e foi aplicado também o teste de Mann-Whitney, com nível de significância de 5\%. Resultados - Os pacientes com doenças malignas ficaram internados por mais tempo $(P<0.0001)$, sendo constatado ainda neste grupo, maior percentual de pacientes com índice de massa corporal $<18.5(P<0.0001)$ e alteração de peso $(P=0.0002)$. Na contagem de linfócitos, constatou-se diferença estatística entre os grupos $(P=0,0131)$, sendo os menores valores encontrados entre os pacientes com doenças malignas $(P=0.01)$. Conclusão - A contagem de linfócitos, os valores de hemoglobina e a perda ponderal são achados importantes de depleção nutricional em pacientes com doenças malignas.

DESCRITORES - Estado nutricional. Perda de peso. Contagem de células sanguíneas. Tempo de internação.

\section{REFERENCES}

1. Barreto Penié J, Cuban Group for the Study of Hospital Malnutrition. State of malnutrition in Cuban hospitals. Nutrition. 2005;21:487-97.

2. Caro MM, Laviano A, Pichard C, Candela CG. Relationship between nutritional intervention and quality of life in cancer patients. Nutr Hosp. 2007;22:337-50.

3. Dias VM, Barreto APM, Coelho SC, Ferreira FMB, Vieira GBS, Cláudio MM, Silva PDG. O grau de interferência dos sintomas gastrintestinais no estado nutricional do paciente com câncer em tratamento quimioterápico. Rev Bras Nutr Clin. 2006;21:211-8.

4. Dossus L, Kaaks R. Nutrition, metabolic factors and cancer risk. Best Pract Res Clin Endocrinol Metab. 2008;22:551-71

5. Esper DH, Harb WA. The cancer cachexia syndrome: a review of metabolic and clinical manifestations. Nutr Clin Pract. 2005;20:369-76.

6. Fonck M, Gékière JP, Blanc-Bisson C, Bourdel-Marchasson I. [State of nutrition and cancer in the elderly]. Bull Cancer. 2008;95FMC:F116-20.

7. Horsley P, Bouer J, Gallagher B. Poor nutritional status prior to peripheral blood stem cell transplantation is associated with increased length of hospital stay. Bone Marrow Transplant. 2005;35:1113-6.

8. Inui A. Cancer anorexia-cachexia syndrome: current issues in research and management. CA Cancer J Clin. 2002;52:72-91.

9. Laboratório Fleury. Manual de exames 2008/2009. São Paulo; 2008.

10. Leandro-Merhi VA, Tristão AP, Moretto MC, Fugulin NM, Mclellan KCP, Aquino JLB. Estudo comparativo de indicadores nutricionais em pacientes com neoplasias do trato digestório. ABCD Arq Bras Cir Dig. 2008;21:114-9.

11. Lipschitz DA. Screening for nutritional status in the elderly. Prim Care. 1994;22:55-67.

12. Martins C, Moreira SM, Pierosan SR. Interações droga nutriente. $2^{a}$ ed. Curitiba, Nutroclínica, 2003.

13. Morley JE. Pathophysiology of anorexia. Clin Geriatr Med. 2002;18:661-73.

14. Mullen JT, Davenport DL, Hutter MM, Hosokawa PW, Henderson WG, Khuri SF, Moorman DW. Impact of body mass index on perioperative outcomes in patients undergoing major intra-abdominal cancer surgery. Ann Surg Oncol. 2008; $15: 2164-72$
15. Osada J, Kamocki Z, Rusak M, Dabrowska M, Kedra B. [The effect of surgical and nutritional treatment on activation parameters of peripheral blood $\mathrm{T}$ lymphocytes in stomach cancer patients in postoperative period]. Pol Merkur Lekarski. 2008;24:231-6.

16. Ottery FD. Definition of standardized nutritional assessment and interventional pathways in oncology. Nutrition. 1996;12:S15-19.

17. Pirlich M, Schütz T, Kemps M, Luhman N, Burmester GR, Baumann G, Plauth M, Lübke HJ, Lochs H. Prevalence of malnutrition in hospitalized medical patients: impact of underlying disease. Dig Dis. 2003;21:245-51.

18. Pirlich M, Schütz T, Norman K, Gastell S, Lübke HJ, Bischoff SC, Bolder U, Frieling T, Güldenzoph H, Hahn K, Jauch KW, Schindler K, Stein J, Volkert D, Weimann A, Werner H, Wolf C, Zürcher G, Bauer P, Lochs H. The German hospital malnutrition study. Clin Nutr. 2006;25:563-72.

19. Ravasco P, Monteiro Grillo I, Camilo M. Cancer wasting and quality of life react to early individualized nutritional counseling. Clin Nutr. 2007;26:7-15.

20. Riso S, Aluffi P, Brugnani M, Farinetti F, Pia F, D'Andrea F. Postoperative enteral immunonutrition in head and neck cancer patients. Clin Nutr. 2000;19:407-12.

21. SAS System for Windows (Statistical Analysis System), version 9.1.3 Service Pack 3. SAS Institute Inc, 2002-2003, Cary, NC, USA.

22. Senesse P, Assenat E, Schneider S, Chargari C, Magné N, Azria D, Hébuterne X. Nutritional support during oncologic treatment of patients with gastrointestinal cancer: who could benefit? Cancer Treat Rev. 2008;34:568-75.

23. Trabal J, Leyes P, Forga MT, Hervás S. Quality of life, dietary intake and nutritional status assessment in hospital admitted cancer patients. Nutr Hosp. 2006;21:505-10.

24. Ulibarri JI, Burgos R, Lobo G, Martínez MA, Planas M, Pérez de la Cruz A, Villalobos JL. [Recomendations for assessing the hyponutrition risk in hospitalised patients]. Nutr Hosp. 2009;24:467-72.

25. Ulsenheimer A, Silva ACP, Fortuna FV. Perfil nutricional de pacientes com câncer segundo diferentes indicadores de avaliação. Rev Bras Nutr Clin. 2007;22:292-7.

26. Van Cutsem E, Arends J. Thecauses and consequences of cancer-associated malnutrition. Eur J Oncol Nurs. 2005;9:s51-63.

27. World Health Organization - WHO. The World Health Report 1998: Life in the 21st century a vision for all. Geneva: WHO; 1998. p. 61-111.

Received 16/9/2009. Accepted 4/10/2010 